\title{
An assessment of areal and transect-based historic shoreline changes in the context of coastal planning
}

\author{
David Griffiths $^{1} \cdot$ Chris House $^{2}$ (D) $\cdot$ Nelson Rangel-Buitrago $^{3} \cdot$ Tony Thomas $^{4}$
}

Received: 17 April 2018 / Revised: 10 July 2018 / Accepted: 9 September 2018 /Published online: 17 September 2018

(C) The Author(s) 2018

\begin{abstract}
With increasing sea levels and anthropogenic coastal pressure, it is more important than ever to develop coastal zone management techniques that are based on sound scientific methodologies. In this paper shoreline change rates were calculated for Port Eynon Bay, Gower, Wales, UK, using a two-step approach (areal and transect-based), to predict future shoreline position and propose management strategies. A Geographical Information System (Qgis) was utilised to calculate shoreline position from historical aerial photographic evidence covering a 60-year period (1944-2014). Results highlighted an increase in the vegetation of $0.41 \mathrm{~km}^{2}$ and a seaward migration of the shoreline $\left(0.3 \mathrm{~m} / \mathrm{yr}^{-1}\right)$; temporal linear regression models constructed around the cumulative data confirmed a consistent trend of areal increase and shoreline migration. Wind components were qualitatively linked to shoreline changes. Models created to predict shoreline position at 10-year and 50-year epochs can be aligned with shoreline management plans and inform embayed beach shoreline assessments at all scales. A management process model was developed based upon the application of transect and areal assessments that can be utilised to inform CZM by identifying locations of vulnerability, enabling management strategy development, that improves resilience under scenarios of sea level rise and climate change.
\end{abstract}

Keywords Coastal planning $\cdot$ Coastal erosion $\cdot$ QGIS $\cdot$ Coastal management $\cdot$ Port Eynon

Chris House

chris.house@uwtsd.ac.uk

David Griffiths

ucfadng@ucl.ac.uk

Nelson Rangel-Buitrago

nelsonrangel@mail.uniatlantico.edu.co

Tony Thomas

t.thomas@pembrokeshire.ac.uk

1 University College London, Pearson Building, Gower Street, London WC1E 6BT, UK

2 Coastal and Marine Research Group, University of Wales Trinity Saint David (Swansea), Technium 2, Kings Road, Swansea, Wales SA1 8PH, UK

3 Departamentos de Física y Biología, Universidad del Atlantico, Barranquilla, Atlantico, Colombia

4 Department of Construction and Engineering, Pembrokeshire College, Merlins Bridge, Haverfordwest, Pembrokeshire SA61 1SZ, UK

\section{Introduction}

\section{Coastal processes and data}

In recent times there has been an increase in the number of studies on beach morphodynamic processes (Cowell and Thom 1994; Thomas et al. 2010; El Mrini et al. 2012; Thomas et al. 2016). Understanding coastal processes is fundamental for appropriate coastal planning and the design and shape of human constructions (Bird 1996; Short and Hogan 1994; Anfuso et al. 2001; Bilskie et al. 2014; Hanley et al. 2014; Rangel-Buitrago et al. 2015). Hence, to improve coastal planning practice, it is important to identify and understand the present and past coastal processes so that a diachronic approach can help inform present and future management strategies. However, most coastal locations have not got the scientific data over a suitable timescale to engage with this method so proxy indicators, such as aerial imagery, have been used to inform management strategies and adopt resilience concepts to coastal locations.

Many beaches are located in the lee of natural or artificial headlands that influence beach evolution. Furthermore, they 
often feature shoreline geometry that is described as a zeta, log spiral or a parabolic curve shape and more than $50 \%$ of the world's coastlines are representative of this morphology (Short and Masselink 1999). Embayed beaches are wellknown for the prominent curvature of their shorelines and are often observed in states of dynamic or static equilibrium (Carter 1988). They are typically assumed to be influenced by some physical environmental factors that contribute to reshaping both the beach profile and plan-form (Short amd Masselink, 1999; Cooper et al. 2007). These factors include underlying geology, sediment volume and composition, and external environmental conditions, such as incident wave characteristics, i.e., height, period, and particularly direction (Cowell and Thom 1994; O'Connor et al. 2007; RangelBuitrago et al. 2016). Also, variability can occur at temporal scales that vary from a few seconds to several years (Carter 1988). These environmental factors determine induced sediment transport both in onshore/offshore and alongshore directions (Komar 1971; Rogers et al. 2010). Shelter induced by beach headlands and nearshore bathymetry further complicate beach behaviour and the scientific methods needed to inform management (Benedet et al. 2004; Ranasinghe et al. 2004). However, erosion and accretion is also affected by coastal processes and are highly vulnerable to storms. Therefore, climate change, weather patterns, impacts on coastal defences and the fate of coastal communities highlight the need for effective planning and it is vital that data collection and analysis support management decisions (Thomas et al. 2010).

\section{Coastal planning and data}

The shoreline definition for coastal research is often taken to be the mean high water level (MHWL) (Simm et al. 1996; Zhang et al. 2002) or vegetation lines (Morton 1991; Boak and Turner 2005). Shoreline changes are due to natural processes, but the associated impacts can be many times increased by human interventions, primarily linked to an inexistent or inappropriate coastal planning (Komar and Allan 2008; Jones and Phillips 2011). Shoreline management requires tools that can integrate scientific knowledge of the compound nature of coastal processes (Phillips and Jones 2006) and yet research shows that science is not always incorporated into planning decisions (House and Phillips 2012).

In England and Wales, coastal planning is implemented through the production of Shoreline Management Plans (SMP) (EA, 2015). These plans recognise that natural processes do not follow the human defined land-based boundaries of administrative authorities, e.g., County Councils, but are based on natural boundaries such as sediment cells. In South Wales, this conceptual development was promoted by Bullen (1993) and during 2000 and 2001 the first generation of the region's SMP was implemented (SBCEG, 2001). The Welsh Government has continued to promote a policy which encourages all organisations with interest in the coastline of Wales to work together and formulate policies and plans that will lead to effective economic and sustainable management of the Welsh coastline. The SMPs are a vital component of this process and provide critical information to interested organisations and stakeholders.

Second generation SMPs (2) reviewed and took account of the latest available information that included climate change guidance, modifications to environmental legislation and improved understanding of flood and coastal erosion risk management to provide a long-term sustainable plan for the next 100 years (Halcrow 2010). Consequently, SMP2 considered how a section of coastline was to be managed over epochs, e.g., 25 years, 50 years and 100 years to address issues such as flooding and erosion. Management decisions considered predictions of climate change consequences linked to socioeconomic use, e.g., coastal tourism, etc. (EA 2015). Hence, SMP2 introduced the need for long-term coastal planning which in turn needed valid, coherent and applicable methods to assess shoreline evolution to inform coastal planning.

This paper assesses long-term shoreline evolution at Port Eynon, UK (SMP2), expressed through cross-shore migration and consecutive realignment, utilising the vegetation line as a proxy shoreline change indicator. Results are compared and contrasted with historical wind strength and directional data, to identify cause and effect. Identified long-lasting changes in coastal processes led to the development of regression models describing shoreline evolution. These established links and relationships have consequences for embayed beach management strategies within the region, and the approach shows the application has potential to other coastal locations with similar proxy data opportunities and planning needs.

\section{Study area}

The Bristol Channel on the West coast of The United Kingdom (Fig. 1a) separates Wales from Southwest England (Fig. 1b). Port Eynon Bay, South Wales, UK (51 $32^{\prime} 43^{\prime \prime N}$ $4^{\circ} 12^{\prime} 54^{\prime \prime} \mathrm{W}$; Fig. 1c), is located on the peninsula that separates two large sweeping embayments, Swansea Bay to the east and Carmarthen Bay to the west. The region is characterised by cliffs and pocket beaches formed as a consequence of the erosion of mudstone-rich Carboniferous coal measures (Halcrow 2010). As such, the study area is located between two Carboniferous Limestone headlands that rise approximately $60 \mathrm{~m}$ above Ordnance Datum (AOD), the distance between headlands being approximately $1.5 \mathrm{~km}$. The embayment profile is shallow and concave, with a wide (circa $300 \mathrm{~m}$ ) sandy intertidal zone. Bordered with an unstable and dynamic dune system, accepted longshore transport is limited and west to east in direction (SBCEG 1999; Fig. 1d).

Semi-diurnal and macrotidal, this swell dominated coastline has a mean spring tidal range of $8.1 \mathrm{~m}$, with a Mean High 

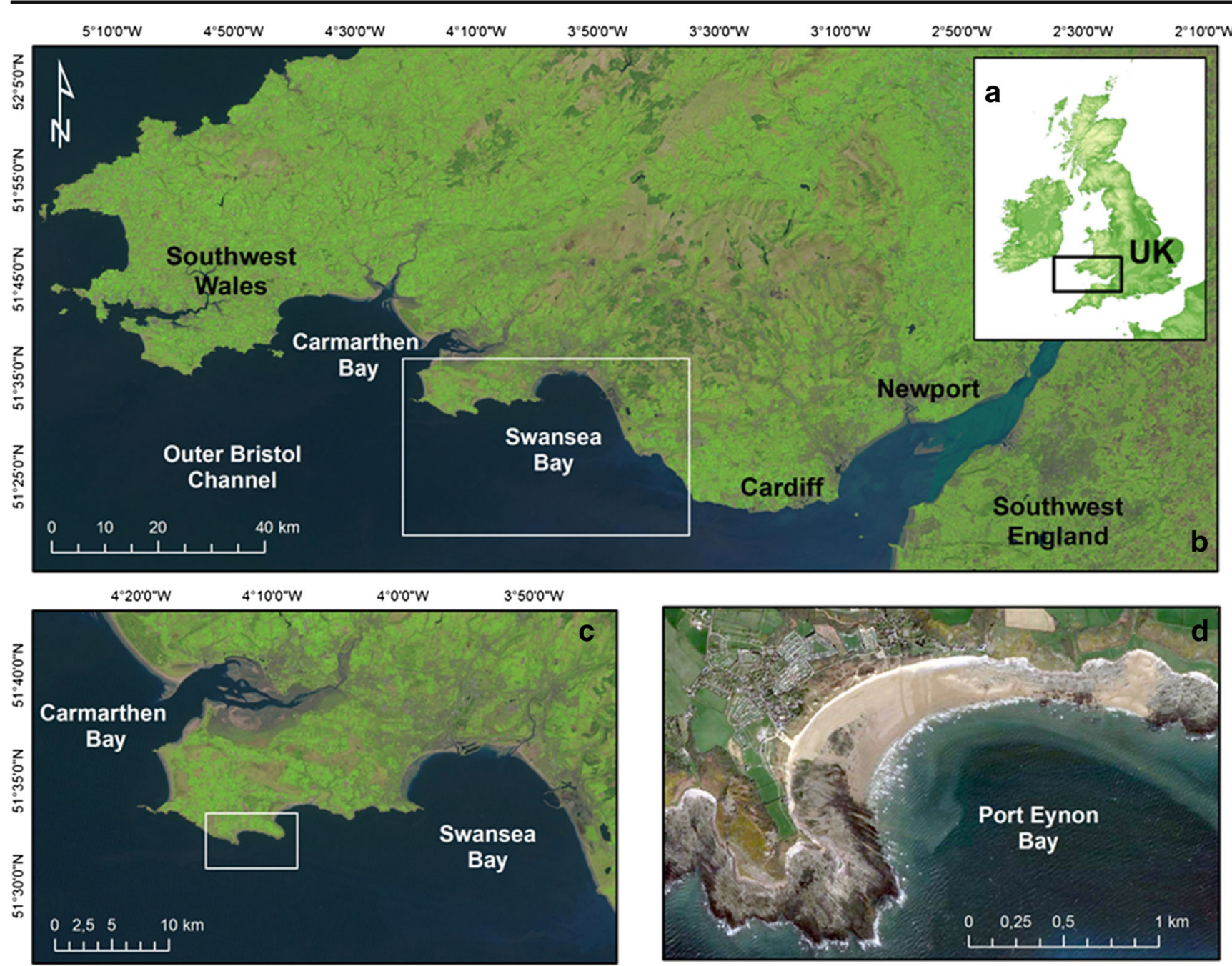

Fig. 1 Locality of the study area: (a) United Kingdom; (b) Bristol Channel; (c) Swansea Bay and the Gower Peninsula and d) aerial photograph (Ordance Survey) showing Port Eynon Bay

Water Spring Tide level (MHWST) of $5 \mathrm{~m}$ (AOD). Incident offshore waves predominantly approach from the southwest with an average wave height of circa $1.2 \mathrm{~m}$ and associated mean periods of $5.2 \mathrm{~s}$ (Thomas et al. 2012). However, storm waves of $7 \mathrm{~m}$, with periods of $9.3 \mathrm{~s}$ make up $5 \%$ of the wave record (Rangel-Buitrago et al. 2016). Longshore drift is influenced by heavily refracted south-westerly Atlantic swell waves which undergo diffraction as they encounter Port Eynon Point Headland (Fig. 1d). Between November 2013 and March 2014, a total of 32 storms (average hs $>3.4 \mathrm{~m}$ ) were recorded generating average waves that reached $4.7 \pm$ $1.26 \mathrm{~m}$ with associated periods of $7.9 \pm 1.00 \mathrm{~s}$, some waves reaching $9.3 \mathrm{~m}$ with periods of $12 \mathrm{~s}$.

Port Eynon is recognised for its scenic beauty and was designated the first Area of Outstanding Natural Beauty (AONB) in the UK in 1956 (Robinson and Millward 1983). Furthermore, the bay is a designated a Heritage Coast (Swansea.gov.uk 2017) and includes four Sites of Special Scientific Interest (SSSI), the South West Wales Special
Area of Conservation (SAC) and two Wildlife Trust nature reserves. The area is regionally important for seabirds, limestone grassland flora and notably its rocky shore, beach and relict dune grassland. Additionally, the bay is significant for its intertidal zone, pelagic birds and is an important roosting site for winter visiting waders (Wildlife Trust 2016).

The coastal management of the study area is principally based on its importance to tourism and environmental designations coordinated by the City and County of Swansea (CCS). Many management strategies within the area are focused on maintaining Blue Flag status (since 2004). Research shows that the main attraction is "a beautiful beach, a family beach, a long stay beach" and therefore the understanding of beach processes will be a determining factor in the area's economy (The Tourism Company 2015: 24). Hence, the understanding and management of beach processes is a prerequisite to the future tourism and conservation value of the area (Phillips and House 2009). 


\section{Methodology}

\section{Shoreline change modeling}

Assessing coastal evolution, and associated shoreline surveys are crucial to the development of suitable management strategies (Anfuso et al. 2011). Long-term beach change rates are traditionally estimated by analysing aerial photographs, historical maps and various forms of topographic survey techniques (Zhang et al. 2002; Sorensen 2006). Standard vertical air photographs employed for photogrammetric measurement of land topography are frequently used in coastal studies (Moore 2000; Sorensen 2006). Within the region of this research, Thomas et al. (2010), Thomas et al. 2013 and Thomas et al. 2016) utilised historical aerial photographs to identify long-term (post World War II) coastal change influenced by wind shifts that caused shoreline displacement resulting in updrift erosion, down-drift accretion and subaqueous loss around the down-drift headland. A fundamental consideration for mapping change is the shoreline proxy indicator. Furthermore, an ideal position indicator is one that is easily identified both in the field and on aerial photographs (Zhang et al. 2002; Leatherman 2003; Parker 2003; Boak and Turner 2005). Douglas and Crowell (2000) argued that uncertainty in shoreline position data depends on accuracy and precision of survey measurements together with the stability of shoreline position indicators. It is critical that any uncertainty in shoreline position is properly accounted for, to statistically test for shoreline change signals (Ruggiero et al. 2003).

This study used aerial photographic evidence to assess morphological change between 1944 and 2014. Nine aerial photographs, all geo-rectified in a Geographic Information System (Qgis $®)$ to the British grid reference system were used to extract shoreline position (Table 1). Errors in aerial photographs can be of the order of $7.5 \mathrm{~m}-8.9 \mathrm{~m}$ caused by distortion and the digitizing process itself (Crowell et al. 1991;

Table 1 Aerial photographic source document scales and RMSE results after digitising

\begin{tabular}{lll}
\hline Year & $\begin{array}{l}\text { Root mean } \\
\text { square error }(\mathrm{m})\end{array}$ & Scale \\
\hline 1944 & 14.0 & $1 / 10,000$ \\
1947 & 1.7 & $1 / 10,000$ \\
1969 & 7.0 & $1 / 10,000$ \\
1981 & 5.6 & $1 / 10,000$ \\
1992 & 11.0 & $1 / 10,000$ \\
1994 & 8.1 & $1 / 10,000$ \\
1999 & 5.3 & $1 / 10,000$ \\
2006 & 5.4 & Digitised $40 \mathrm{~cm}$ resolution \\
2014 & 2.6 & Digitised $40 \mathrm{~cm}$ resolution \\
Average & 6.8 & \\
\hline
\end{tabular}

Douglas and Crowell 2000). Root Mean Square Error (RMSE) was calculated using RMSE $=\left[\left(\sum\left(\mathrm{N}_{\mathrm{c}}-\mathrm{N}_{\mathrm{t}}\right)^{2}+\sum\left(\mathrm{E}_{\mathrm{c}}\right.\right.\right.$ $\left.\left.\left.-\mathrm{E}_{\mathrm{t}}\right)^{2}\right) / \mathrm{n}\right]^{1 / 2}$, where; $\mathrm{N}_{\mathrm{t}}$ and $\mathrm{E}_{\mathrm{t}}$ are calculated coordinates from the photo transformation. $\mathrm{N}_{\mathrm{c}}$ and $\mathrm{E}_{\mathrm{c}}$ are control coordinates, and $\mathrm{n}$ is the total number of data points. Table 1 shows respective source document scales and RMSE values. The average RMSE error for the aerial photographs was $6.75 \mathrm{~m}$. Similar to Thomas et al. (2010, 2014 and 2016), distortion error was mitigated using 600 dpi images, and digitizing errors were assessed for accuracy using RMSE (see Maune 2007 for a theoretical interpretation). Subsequently, survey control points were established with an average of 200 readings taken at every control point. Horizontal and vertical control was achieved using GNSS with data derived directly from the OS Net. The surveying equipment comprised of a Geomax Zenith 25 receiver capable of acquiring data horizontally at $\pm 10 \mathrm{~mm} 1 \mathrm{ppm}$ (rms) and vertically at $20 \mathrm{~mm} \pm 1 \mathrm{ppm}$ (rms). A receiver housing a SIM card and Q-lock, satellite tracking technology, was mounted on top of a $2 \mathrm{~m}$ pole.

In line with the seminal works of Morton (1991), the vegetation line was chosen as the shoreline change indicator, as this could be identified on all aerial photographs and is valuable for investigating long-term trends (Boak and Turner 2005; Thomas et al. 2010 and Thomas et al. 2016). The corresponding extracted shoreline position was imported into the Regional Morphological Analysis Programme - RMAP (see Morang et al. 2009 for theoretical interpretation and Thomas et al. 2010, 2012 and Thomas et al. 2016 for practical applications). RMAP is a module within the Coastal Engineering Design and Analysis System (CEDAS), where inter-survey and cumulative shoreline changes can be evaluated. Temporal change analysis was achieved using the 1947 shoreline position as a proxy baseline. The shoreline positions measured from aerial photographs were extracted along 15 theoretical transects (T1-T15), spaced approximately $100 \mathrm{~m}$ apart (Fig. 2). Linear regression analysis was used to determine both transect, and areal based temporal changes. This methodology has been successfully applied in other studies worldwide. For example, Douglas and Crowell (2000), Short (1999) and in the immediate region of study by Thomas et al. 2010 and Thomas et al. 2016. Mostly, transect variation was assessed by 15 shoreline signals and areal change by the variation in the area between these transects.

\section{Wind data characterization}

Waves play a major role in coastal flooding and sediment relocation (Komar 1998) and along with their directional components are used as direct input into coastal engineering or coastal zone management calculations (Turki et al. 2013). The wind is a significant influence in beach-dune sediment interactions and may increase mean water level during storm conditions. Even though this component is the underlying 


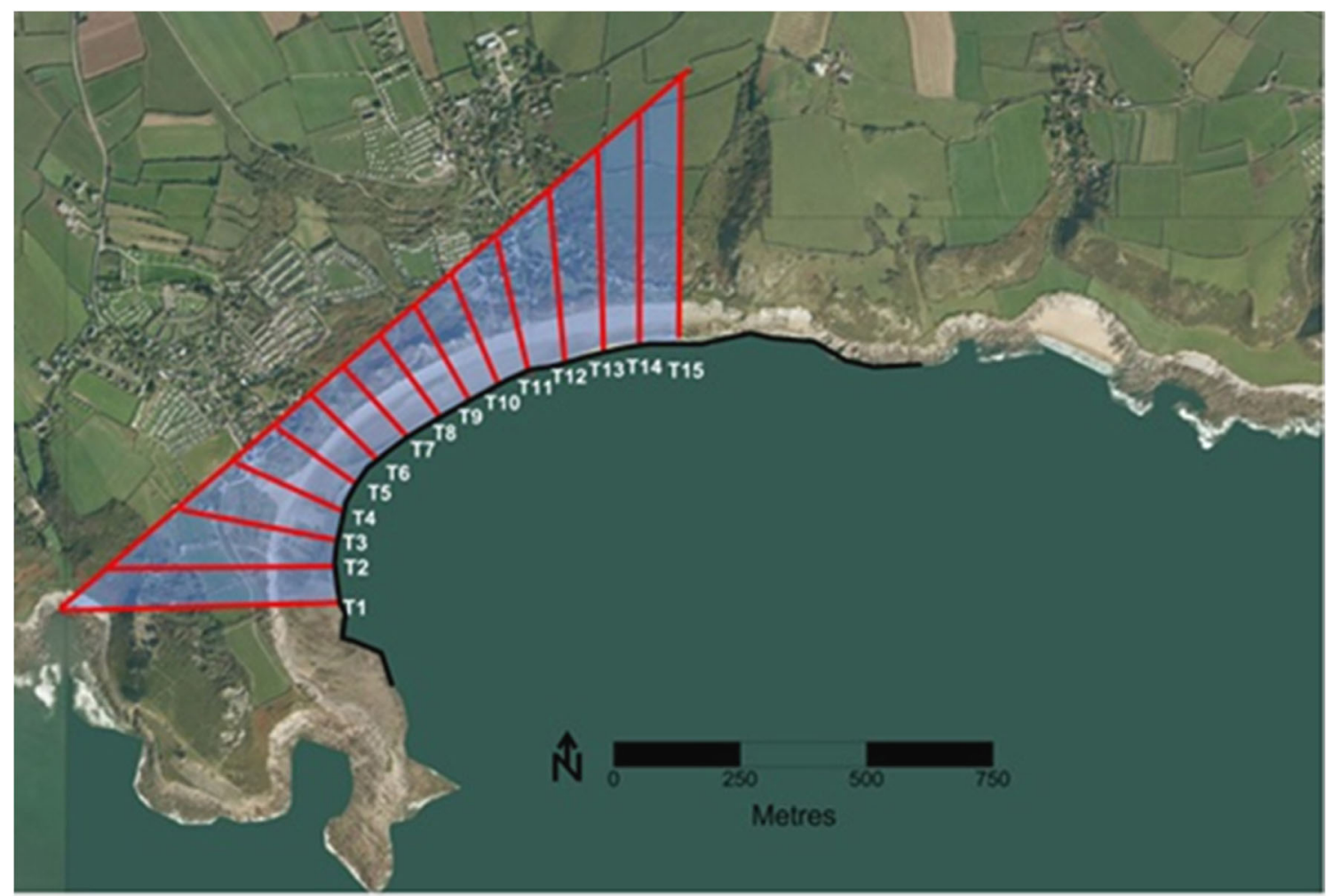

Fig. 2 An aerial photograph (Ordance Survey) depicting the 15 transects (red lines) from which shoreline change was assessed

cause of most sources of coastal flood and erosion risk, data is rarely considered (Rogers et al. 2010). In the present region of study, storm strength (wind speed and direction) was correlated to erosional events (Thomas et al. 2010), but this work did not establish that wind was the primary cause of erosion.

Within the region of study, synthesised wind and wave time series from numerical meteorological models that were suitable to be input into wave prediction models, have only recently been made available. However, wind speed and directional data from the early 1940s were available and obtained from the UK Meteorological Office, enabling direct comparisons to be made between shoreline change and these environmental forcing agents. Offshore wind speed and direction data were captured at approximately 3 -h intervals at a point southeast of the study area $\left(51^{\circ} 24^{\prime} 00^{\prime \prime} \mathrm{N} ;-5^{\circ} 00^{\prime} 00^{\prime} \mathrm{W}\right)$. Some of the early data was missing; the dataset contained circa 147,000 independent values.

\section{Results}

\section{Area of change}

Table 2 shows the inter-survey, and cumulative areal changes between 1944 and 2014 and inter-survey results demonstrate that there was a landward shoreline migration from 1947 to 1969 , 1994 to 1999 and 2006 to 2014. That was compensated by seaward shoreline migrations, with the most rapid excursion
Table 2 Area changes between 1944 and 2014

\begin{tabular}{llll}
\hline Timescale & Area $\left(\mathrm{km}^{2}\right)$ & $\begin{array}{l}\text { Inter-survey areal } \\
\text { change }\left(\mathrm{km}^{2}\right)\end{array}$ & $\begin{array}{l}\text { Cumulative areal } \\
\text { change }\left(\mathrm{km}^{2}\right)\end{array}$ \\
\hline 1944 & 5.34 & & \\
1947 & 5.40 & 0.06 & 0.06 \\
1969 & 5.24 & -0.17 & -0.11 \\
1981 & 5.35 & 0.11 & 0.00 \\
1992 & 5.79 & 0.45 & 0.45 \\
1994 & 5.85 & 0.06 & 0.51 \\
1999 & 5.84 & -0.02 & 0.49 \\
2006 & 5.87 & 0.04 & 0.53 \\
2014 & 5.75 & -0.12 & 0.41 \\
\hline
\end{tabular}


occurring between 1981 and $1992\left(0.447 \mathrm{~km}^{2}\right)$, culminating in an overall advancement of $0.41 \mathrm{~km}^{2}$ over the 60 year assessment period. Regression models constructed from Table 2 data, show that there was no correlation between inter-survey areal change, indeed the regression equation $(y=0.00 \times+0.292$; Fig. 3a) explained none of the data variation $(p>0.05)$.

However, this result is not surprising as other regional studies demonstrate similar results (see for example Thomas et al. 2011). When cumulative values were assessed, a positive relationship exists and is indicative of a temporal areal increase given by the regression equation $y=0.009 \times+18.32$, (Fig. 3b) and an $\mathrm{R}^{2}$ value that explains $60 \%$ of data variation that is statistically significant at $99 \%$ confidence $(p=0.00)$. The lack of correlation between inter-survey areal change and time (Fig. 3a) can be interpreted as constant areal change. Hence, the rate of change is not varying in time. This statement is supported by a linear increase in cumulative change, as demonstrated by Fig. 3 b.

The inter-survey areal changes superimposed upon the 2014 aerial photograph (Fig. 4), show a lack of vegetation around the beach access, probably caused by dune trampling. Change in this area is highlighted by relative seaward migration during the period 1981-1992. Further east in the central part of the bay there was also a seaward migration and areal increases that mostly occurred between 1961 and 1992.

\section{Shoreline rates of change}

Table 3 extrapolated from RMAP shows both inter-survey and cumulative shoreline change rates for the period between 1994 and 2014. Inter-survey results demonstrate that the shoreline advanced 1.0 myr $^{-1}$ between 1944 and 1947 and this culminated in an overall increase of $2.6 \mathrm{~m}$. There was a reversal in trend over the subsequent 22 yrs. to 1969 , where the shoreline migrated landward by $5.9 \mathrm{~m}\left(0.3 \mathrm{~m} \mathrm{yr}^{-1}\right)$. There then followed a period of recovery, where shoreline change rates increased consistently, from $0.4 \mathrm{myr}^{-1}$ to $2.5 \mathrm{myr}^{-1}$, culminating in an overall shoreline migration of $33 \mathrm{~m}$. A reversal in mean trend showed the shoreline migrating landward 1994-1999 and 2006-2014 by $3.5 \mathrm{~m}\left(0.7 \mathrm{~m} \mathrm{yr}^{-1}\right)$ and
Fig. 3 Graphical representations depicting 1944-2014, a) intersurvey areal change and b) cumulative areal change
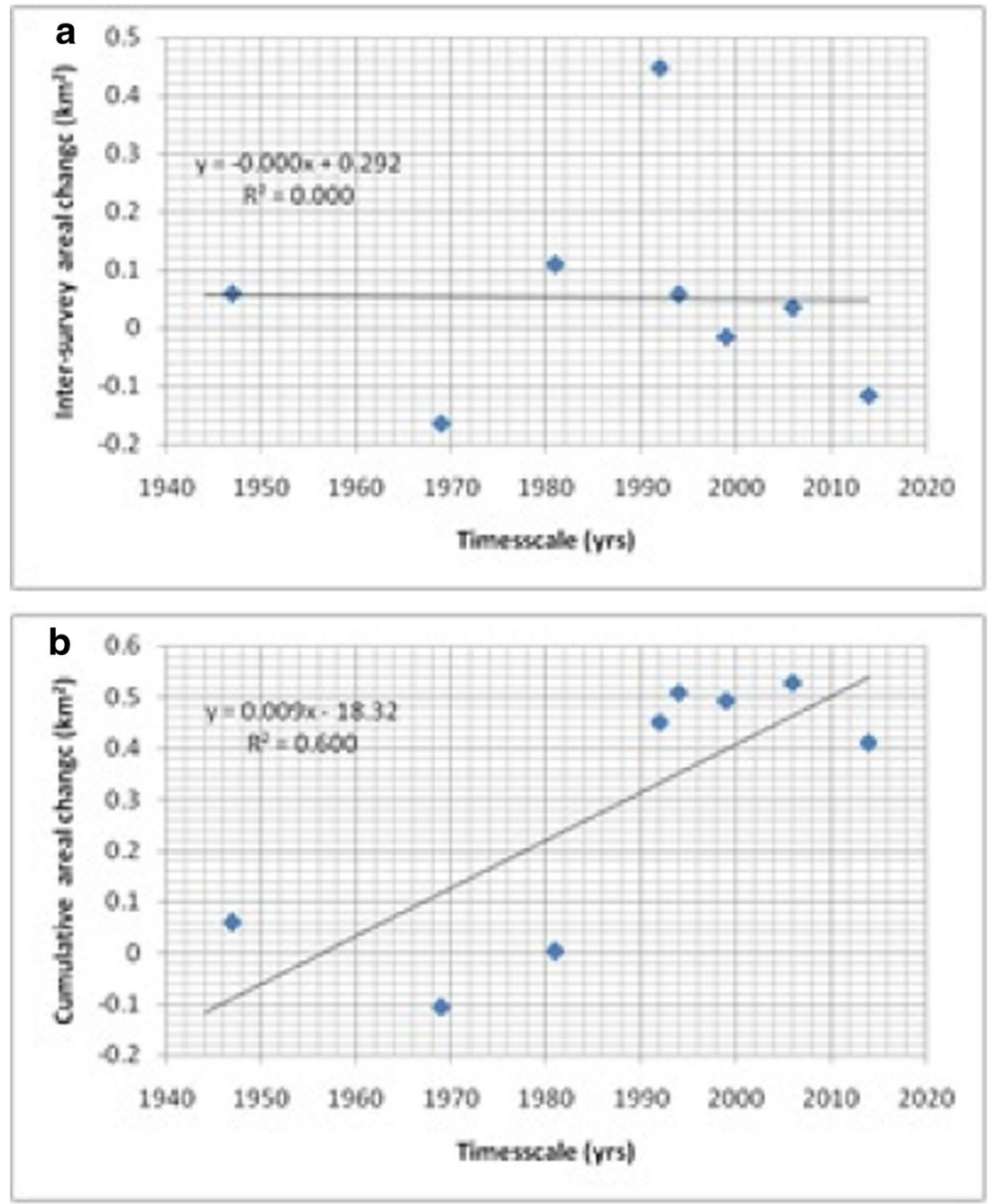


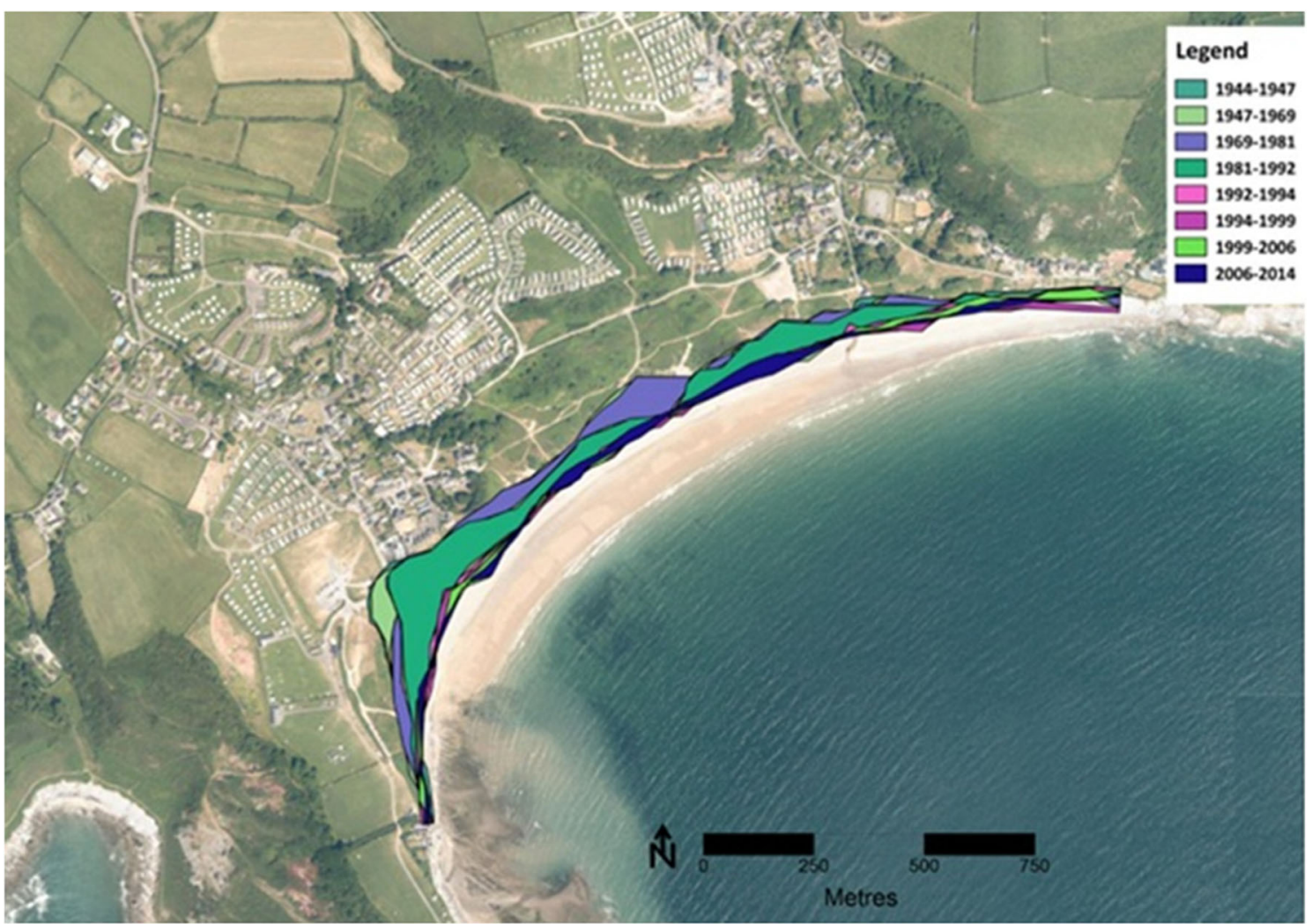

Fig. 4 Areal change polygons superimposed upon 2014 aerial photograph (Ordance Survey)

$5.17 \mathrm{~m}\left(0.7 \mathrm{~m} \mathrm{yr}^{-1}\right)$ respectively, and in between these periods, the opposite was true with a seaward migration of the shoreline by $6.6 \mathrm{~m}\left(1.0 \mathrm{~m} \mathrm{yr}^{-1}\right)$. The cumulative results confirm an overall seaward shoreline migration during the assessment period of $21 \mathrm{~m}$ representing an annual increase of $0.3 \mathrm{~m} \mathrm{yr}^{-1}$. However, results show relative landward shoreline migration between 1944 and 1981 of $0.1 \mathrm{~m} \mathrm{yr}^{-1}$ (3.2 m).

Regression models, constructed from the data of Table 3 show similar results to areal change models, albeit that intersurvey results show positive correlation indicative of increasing change (as opposed to a negative areal trend). This was given by the regression equation $y=0.014 \times+25.44$, and an $\mathrm{R}^{2}$ value that explained almost none of the data variation
( $p>0.05$; Fig. 5a). Similarly, the cumulative results show a positive trend, but with greater statistical significance given by the regression equation $\mathrm{y}=0.437 \times-856.3$ and an $\mathrm{R}^{2}$ value that explained more than $60 \%$ of data variation $(p<0.00$; Fig. $5 b)$. Similar to previous areal analysis (Fig. 3) the lack of correlation between inter-survey shoreline change rates and time (Fig. 5a) can also be interpreted as constant. Hence, the rate of change is not varying in time. A negative correlation indicative of decreasing shoreline change rates with time was highlighted by the model constructed from cumulative shoreline change rates, and even though the $R^{2}$ value $(p>0.05)$ explains only $11 \%$ of data variation; results suggest that the bay is gradually reaching an equilibrium state (Fig. 5c).
Table 3 Shoreline rates of change between 1944 and 2014

\begin{tabular}{llllll}
\hline $\begin{array}{l}\text { Span of shoreline } \\
\text { change }\end{array}$ & $\begin{array}{l}\text { Average Rate } \\
\left(\mathrm{myr}^{-\mathbf{1}}\right)\end{array}$ & $\begin{array}{l}\text { Average } \\
\text { Change }(\mathrm{m})\end{array}$ & $\begin{array}{l}\text { Span of shoreline } \\
\text { change }\end{array}$ & $\begin{array}{l}\text { Average Rate } \\
\left(\mathrm{myr}^{-\mathbf{1}}\right)\end{array}$ & $\begin{array}{l}\text { Average } \\
\text { Change (m) }\end{array}$ \\
\hline $1944-1947$ & 1.0 & 2.6 & $1944-1947$ & 1.0 & 2.6 \\
$1947-1969$ & -0.3 & -5.9 & $1944-1969$ & 0.0 & -3.4 \\
$1969-1981$ & 0.4 & 4.9 & $1944-1981$ & -0.1 & -3.2 \\
$1981-1992$ & 2.1 & 23.2 & $1944-1992$ & 0.4 & 17.5 \\
$1992-1994$ & 2.5 & 4.9 & $1944-1994$ & 0.5 & 22.9 \\
$1994-1999$ & -0.7 & -3.5 & $1944-1999$ & 0.4 & 19.5 \\
$1999-2006$ & 1.0 & 6.6 & $1944-2006$ & 0.4 & 25.1 \\
$2006-2014$ & -0.7 & -5.2 & $1944-2014$ & 0.3 & 21.0 \\
\hline
\end{tabular}


Fig. 5 Graphical representations depicting a) inter-survey shoreline change rates, $\mathbf{b}$ ) cumulative shoreline change rates $(\mathrm{m})$ and $\mathbf{c}$ ) cumulative shoreline change rates (m yr. ${ }^{-1}$ )
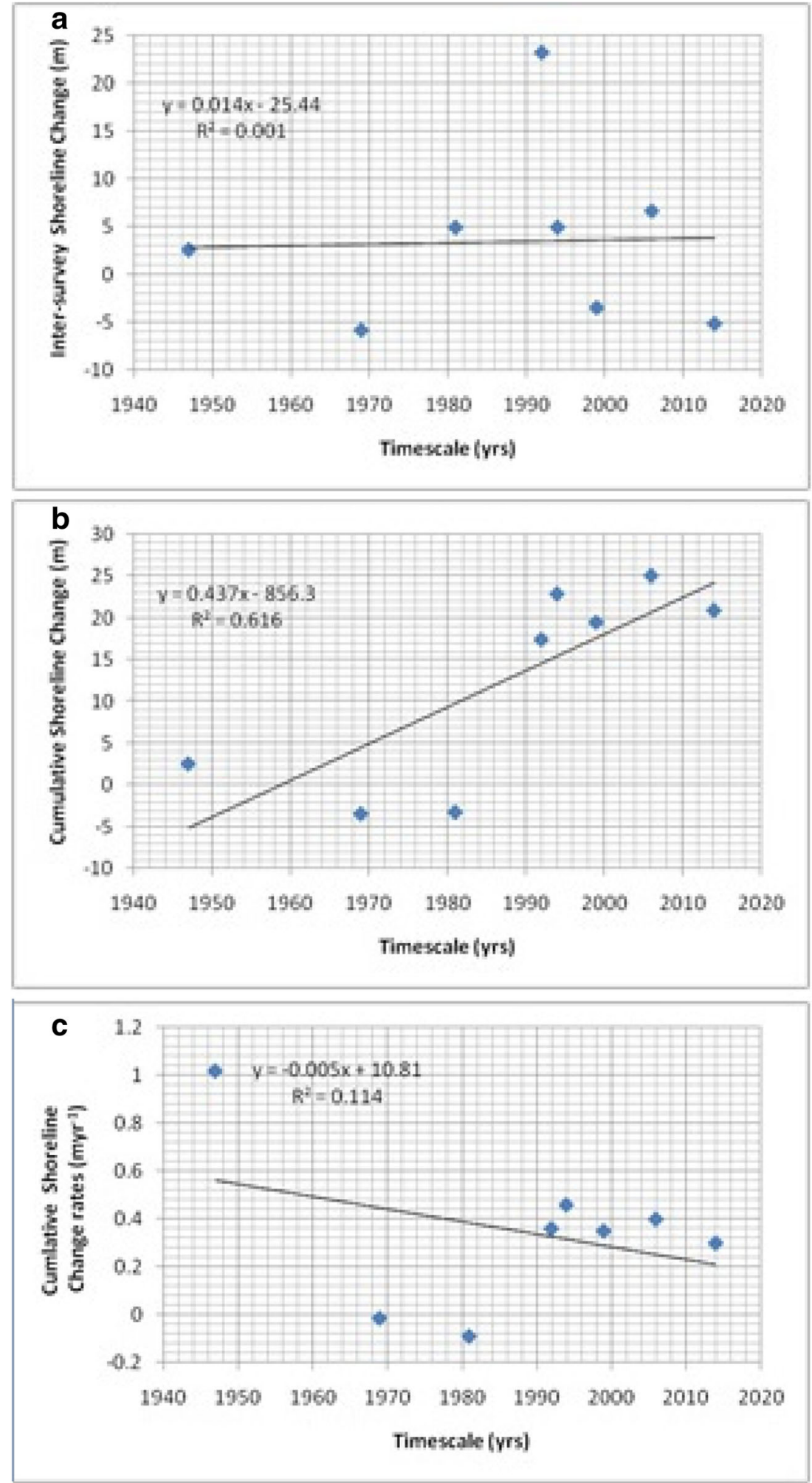

\section{Predicting shoreline evolution}

Direct measurements of the shoreline were taken from the predetermined baseline (Fig. 6) and the results displayed in Table 4 . In order to develop predictive capability, regression models were constructed for each transect, and the results are displayed in Table 5. This methodology differs somewhat from Thomas et al. (2010 and 2016) as these authors averaged the transect measurements between zones. The data of Table 4 show a very definite reduction in the coefficient of determination from 
Fig. 6 Vegetation lines from 1944 to 2014 and transect locations

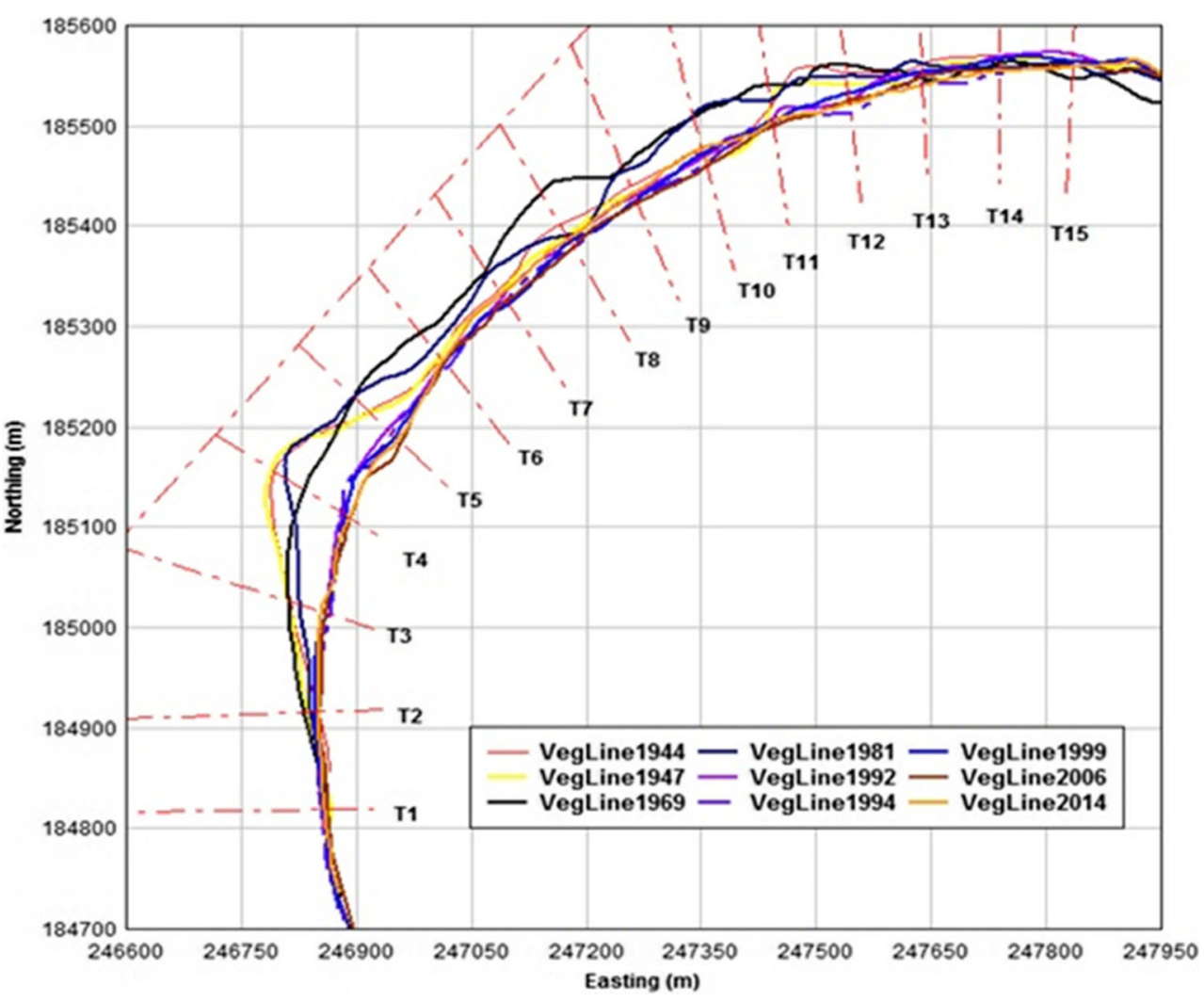

the west towards east and constructed regression models highlight this variation, which is given by the equation $\mathrm{y}=0.032+$ 0.612 and an $\mathrm{R}^{2}$ value that explains over $30 \%$ of data variation $(p<0.05$; Fig. 7a). A positive relationship also exists when overall change is compared with resultant $\mathrm{R}^{2}$. This demonstrates that the greater the shoreline changes that have occurred the higher the correlation. This was given by the eq. $\mathrm{Y}=0.006+0.186$ and

Table 4 Measurements from base line to vegetation line at transect intersections

\begin{tabular}{lrrrrrrrrr}
\hline Transect & 1944 & 1947 & 1969 & 1981 & 1992 & 1994 & 1999 & 2006 & 2014 \\
\hline T1 & 605 & 607 & 601 & 601 & 596 & 597 & 600 & 604 & 598 \\
T2 & 483 & 471 & 466 & 475 & 477 & 483 & 480 & 486 & 485 \\
T3 & 244 & 243 & 242 & 258 & 286 & 291 & 286 & 283 & 278 \\
T4 & 82 & 81 & 130 & 105 & 185 & 183 & 187 & 196 & 195 \\
T5 & 110 & 115 & 90 & 89 & 145 & 150 & 158 & 168 & 161 \\
T6 & 132 & 130 & 89 & 116 & 132 & 142 & 136 & 137 & 135 \\
T7 & 124 & 130 & 101 & 101 & 134 & 139 & 143 & 140 & 128 \\
T8 & 121 & 137 & 86 & 138 & 148 & 154 & 148 & 154 & 144 \\
T9 & 159 & 165 & 136 & 139 & 169 & 174 & 173 & 178 & 168 \\
T10 & 201 & 205 & 165 & 163 & 206 & 215 & 203 & 219 & 197 \\
T11 & 244 & 251 & 217 & 235 & 258 & 258 & 255 & 258 & 258 \\
T12 & 291 & 302 & 282 & 296 & 323 & 332 & 313 & 320 & 323 \\
T13 & 383 & 393 & 394 & 372 & 387 & 398 & 385 & 392 & 398 \\
T14 & 473 & 481 & 483 & 487 & 475 & 492 & 478 & 488 & 487 \\
T15 & 596 & 593 & 611 & 592 & 584 & 586 & 592 & 595 & 596 \\
\hline
\end{tabular}

a statistically significant $\mathrm{R}^{2}$ that explains over $60 \%$ of the data variation $(p<0.00$; Fig. $7 \mathrm{~b})$.

Additionally, Leatherman et al. 1997 suggested that to forecast at 10 and 50-year intervals a 100-year dataset would be required. However, data sets of this longevity are rarely available, and we contend that assessments can be made using a smaller temporal dataset on the proviso that all future collected data is used to inform model refinement. Consequently, the regression equations of Table 5 were applied to assess shoreline position at each transect at 10-year (2024) and 50-year (2064) epochs.

The results of this transposition are given in Table 5 and displayed graphically in Fig. 8. The shoreline at both 10 year and 50-year epochs remained relatively stable. The most noticeable characteristic of the predictions is a seaward excursion that occurred at transect $\mathrm{T} 4$, influenced by rapid vegetation growth near the western access that was observed in the 1944 aerial photograph. The origin of the distinct lack of growth is unclear, but anecdotal evidence suggests that the vegetation was cleared during World War II training exercises. In this case, the model assumed continued significant seaward migration. This is highly unlikely but should be mitigated with further model refinement when data are made available.

\section{Shoreline changes in relation to wind conditions}

Within the region of study, synthesised wind and wave time series from numerical meteorological models suitable for use 
Table 5 Temporal regression analysis results by transect

\begin{tabular}{|c|c|c|c|c|c|c|c|}
\hline \multirow[t]{2}{*}{ Transect } & \multirow{2}{*}{$\begin{array}{l}\text { Change } \\
1944- \\
2014\end{array}$} & \multirow[t]{2}{*}{ Regression Equation } & \multirow[t]{2}{*}{$\mathrm{R}^{2}$} & \multirow[t]{2}{*}{ Signifiance } & \multirow[t]{2}{*}{$\begin{array}{l}\text { Shoreline position } \\
2014\end{array}$} & \multicolumn{2}{|c|}{$\begin{array}{l}\text { Predicted } \\
\text { shoreline } \\
\text { position (m) }\end{array}$} \\
\hline & & & & & & 2024 & 2064 \\
\hline $\mathrm{T} 1$ & -7 & $y=-0.1073 x+813.77$ & 0.5 & $<0.05$ & 598 & 597 & 592 \\
\hline $\mathrm{T} 2$ & 1.9 & $y=0.1426 x+195.71$ & 0.3 & $>0.05$ & 485 & 484 & 490 \\
\hline $\mathrm{T} 3$ & 34 & $y=0.7225 x-1164.7$ & 0.7 & $<0.00$ & 278 & 298 & 327 \\
\hline $\mathrm{T} 4$ & 112.9 & $\mathrm{y}=1.8589-3536.6$ & 0.9 & $<0.00$ & 195 & 226 & 300 \\
\hline $\mathrm{T} 5$ & 50.7 & $y=0.9281 \times-1708.4$ & 0.6 & $<0.05$ & 161 & 170 & 207 \\
\hline T6 & 2.4 & $y=0.2189 \times-306.36$ & 0.1 & $>0.05$ & 135 & 137 & 145 \\
\hline $\mathrm{T} 7$ & 3.7 & $y=0.24 \times-349.36$ & 0.2 & $>0.05$ & 128 & 136 & 146 \\
\hline T8 & 23.7 & $y=0.4883 \times-831.67$ & 0.3 & $>0.05$ & 144 & 157 & 176 \\
\hline T9 & 9.9 & $y=0.275 \times-383.05$ & 0.2 & $>0.05$ & 168 & 174 & 185 \\
\hline $\mathrm{T} 10$ & -3.3 & $y=0.1933 \times-196.2$ & 0.1 & $>0.05$ & 197 & 195 & 203 \\
\hline T11 & 13.8 & $y=0.2793 \times-305.45$ & 0.2 & $>0.05$ & 258 & 260 & 271 \\
\hline $\mathrm{T} 12$ & 31.7 & $y=0.4972 \times-676.79$ & 0.5 & $<0.05$ & 323 & 330 & 349 \\
\hline $\mathrm{T} 13$ & 15.8 & $\mathrm{y}=0.0919+206.99$ & 0.1 & $>0.05$ & 398 & 393 & 397 \\
\hline T14 & 14.2 & $y=0.1259 \times+232.89$ & 0.2 & $>0.05$ & 487 & 488 & 493 \\
\hline T15 & 0.3 & $y=-0.0297 x+650.78$ & 0.03 & $>0.05$ & 596 & 591 & 589 \\
\hline
\end{tabular}

in qualitative and quantitative assessments, have been available only since 1986 . However, comprehensive sets of wind speed and directional data were available from the early $1940 \mathrm{~s}$ and used to assess shoreline behaviour against these imposed environmental forcing agents over a historical timeframe.

The seaward excursion of the shoreline (Table 3 ) took place between 1944 and $1947\left(1.0 \mathrm{myr}^{-1}\right)$ and occurred when both direction $\left(0=206 \pm 16.9^{\circ}\right.$, Fig. $\left.9 \mathrm{a}\right)$ and wind speed $(0=7 \pm$ $0.97 \mathrm{~m} \mathrm{~s}^{-1}$; Fig. 9b) were below average. This suggests that winds predominate from the south toward the east, with a wind speed reduction as a consequence of the limiting Bristol Channel fetch. A reduction in shoreline retreat rates $\left(-0.3\right.$ myr $\left.^{-1}\right)$, was observed between 1947 and 1969 as winds predominated from a south-easterly direction (negative) in the early 1950 s shifted to a south-westerly one towards the middle of the decade, returning towards the mean direction of around $210^{\circ}$ in the late 1950 's. The highest winds during this timeframe also occurred during the early 1950s followed by a period of below average wind speeds. Winds increased, as wind direction fluctuated above and below the mean from 1969 to 1981 . This corresponded with a seaward shoreline migration, reversing the previous trend $\left(0.4 \mathrm{myr}^{-1}\right.$, respectively); wind speed and direction fluctuated between negative and positive values. Wind speed trend was near or below the average value and the direction was predominantly from the southeast during two further periods of shoreline advance of $2.1 \mathrm{myr}^{-1}$, and $2.5 \mathrm{myr}^{-1}$, (during 1981-92 and 1992-94, respectively). However, similar trends in wind speed and direction to previous values were observed between 1994 and
1999 but resulted in a shoreline retreat of $-0.7 \mathrm{myr}^{-1}$. The shoreline returned to advance between 1999 and 2006 (1.0 $\mathrm{myr}^{-1}$ ) when winds were lower than average, and wind direction fluctuated between southwest and southeast. Extreme storms were recorded between late 2013 and early 2014 that caused erosion along the west and central sectors, i.e., a landward excursion of the vegetation line, contributing to an overall frontage loss of $-0.7 \mathrm{myr}^{-1}$, as the eastern sector accreted. Regional wave data covering the period up until the end of 2013 showed that relatively weak wind speeds predominated, suggesting that the bulk of the erosion took place during the January/February storms.

The data of Table 4 data were transformed to characterize inter-survey changes by beach sector (west, T1-T5/central T6T10/east, T11-T15) and compared to wind direction (Fig. 10a) and wind speed (Fig. 10b). The overall accretionary trend highlighted in Table 2 between 1944 and 1947 was restricted to both central and eastern sectors as the western sector eroded under south/southeast (below average) and less energetic wind regimes. When southerly wind directions were encountered under a variable wind speed, there was an increasing trend within the west sector (circa $2 \mathrm{~m}$ ) and losses in both east (circa $7 \mathrm{~m}$ ) and central (circa $38 \mathrm{~m}$ ) sectors between 1946 and 1969. Under less energetic wind speed and directions emanating from the south toward southwest between 1969 and 1981, there is negligible erosion in the west and east sectors and accretionary behaviour within the central sector (circa $16 \mathrm{~m}$ ). South-westerly wind directions and variable below average wind speeds resulted in overall accretion in all three sectors, 
Fig. 7 Graphical representations comparing coefficient of determination derived from transect regression models and a) transect and $\mathbf{b}$ ) overall shoreline change
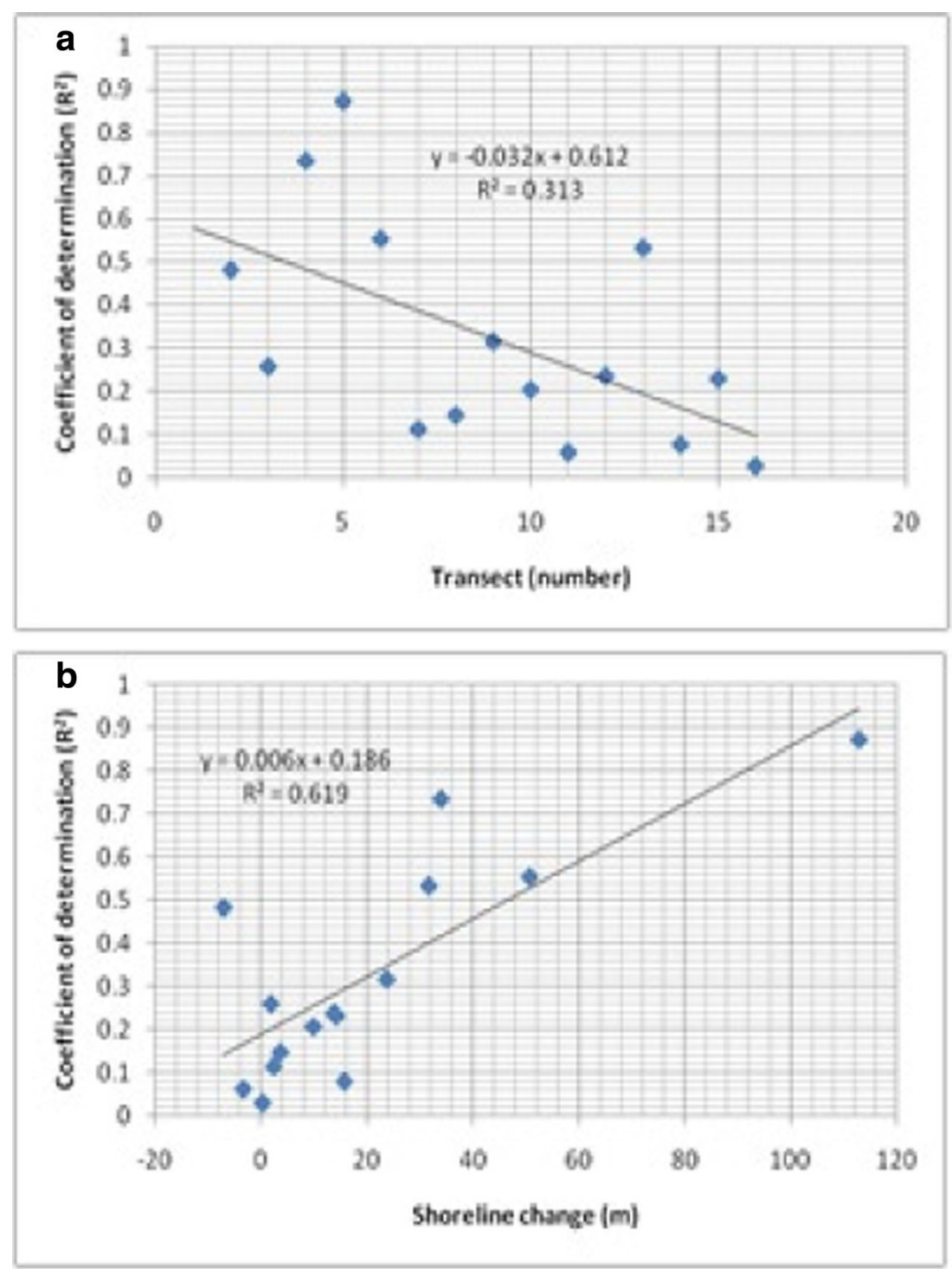

(circa $42 \mathrm{~m}$, circa $34 \mathrm{~m}$ and circa $15 \mathrm{~m}$ west to east), in southern erosion, contrasted against, northern accretion with central

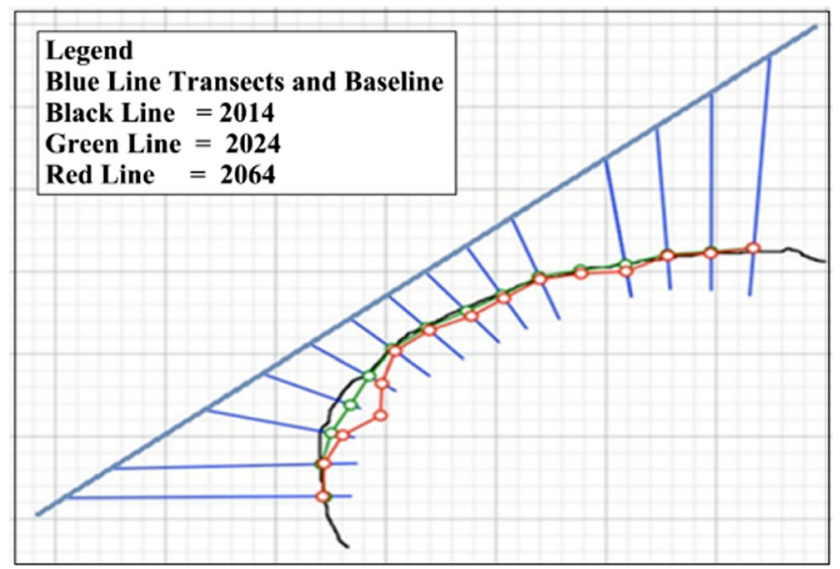

Fig. 8 Graphical representations of the predicted 2024 (green line) and 2064 (red line) shorelines, alongside the measured 2014 shoreline position sectors varying between erosion and accretion throughout (1981-2006). However, this was permeated by losses within the central and eastern sector between 1994 and 1999 of circa $4 \mathrm{~m}$ and circa $8 \mathrm{~m}$ respectively. Under the extreme, southwesterly storm conditions encountered during the 2013/14 winter both west and central sectors eroded, contrasted, against accretion in the east.

\section{Discussion}

SBCEG (2001) recognised that there was an absence of synchronised time-series monitoring data which had resulted in severe constraints on the understanding of shoreline behaviour. Although numerical modelling and data management techniques were being used, there had been little progress in advancing the basic physics of coastal processes. There was a need for coherent time-series monitoring to enable process trends to be more 

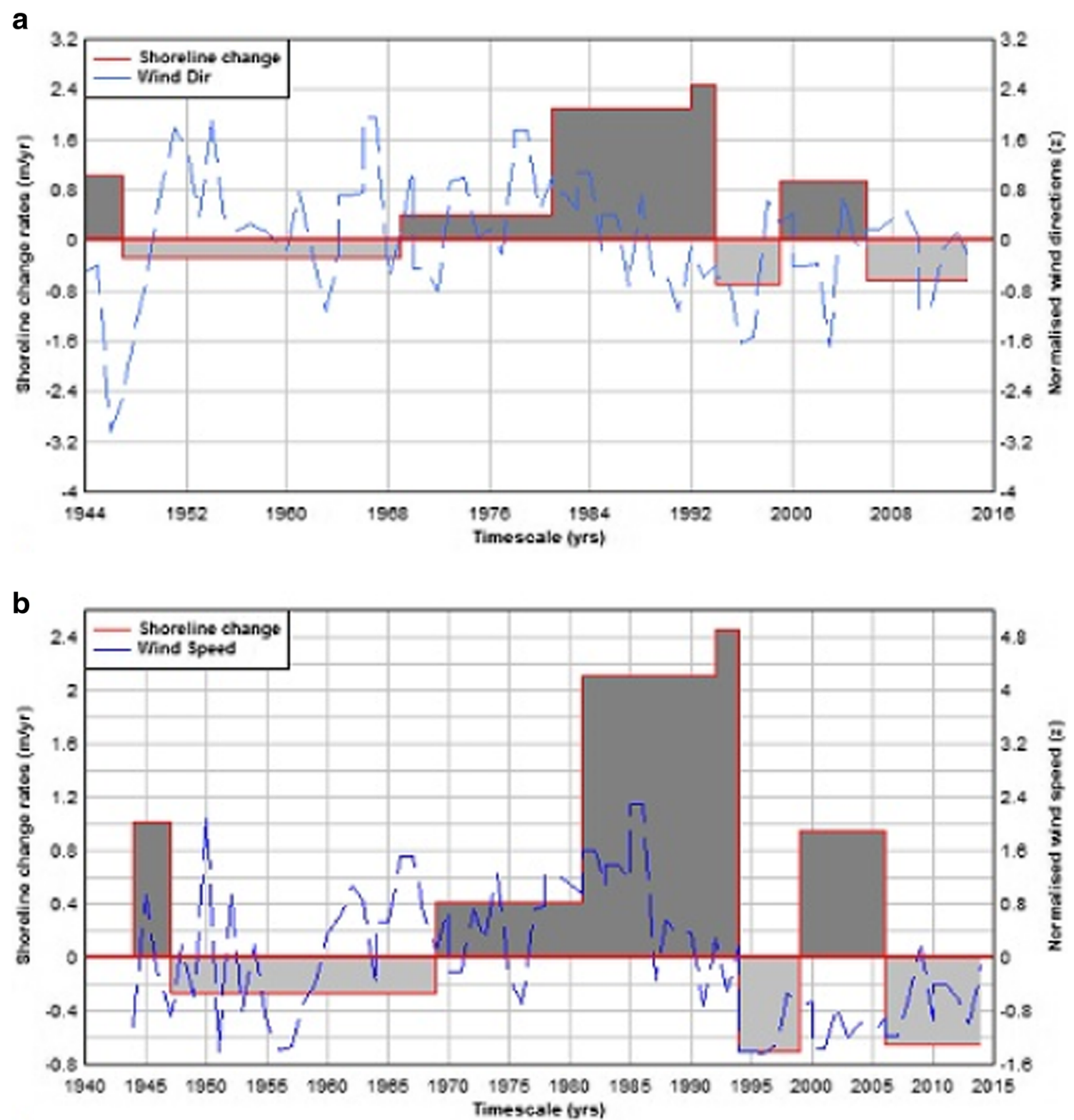

Fig. 9 Comparison of Shoreline change rates (Table 2) and normalized (a) wind direction in degrees clockwise from true north, (b) wind speed for the period 1944 to 2014. Note light grey and negative shoreline change values = erosion and dark grey and positive shoreline change values $=$ accretion

accurately determined, thereby informing the timing and extent of any intervention works. Consequently, the monitoring strategy proposed in SMP1 (first generation SMP) included: annual ground and aerial shoreline inspections; twice yearly beach profile measurements; and inshore wave monitoring. The ground and aerial surveys contextualise the setting, while beach profiles give a level definition of planform and as such, quantitatively define intertidal zone response to the forcing agents of winds, water levels, waves, currents and freshwater inputs. These could then be linked to the more spatially discrete inshore wave monitoring (SBCEG, 2001). SMP1 identified that Port Eynon Bay could experience significant impacts from sea level rise and increased storminess, and the current research supports this view by showing that wind components were qualitatively linked to shoreline change. Sediment movement resulting from marine dredging operations, impacts upon coastal processes, and the real and perceived reduction in beach levels at Port Eynon, were considered major management issues in SMP1. It recognised the importance of these sand beaches for tourism but later work by Phillips (2008) showed that marine aggregate dredging was not a major contributor to their erosion. Furthermore, results from this work showed that, except transects at either end of the bay, temporal linear regression models confirmed a consistent trend of areal increase and shoreline advance.

In times of accelerated sea level rise and increasing demands on beaches to provide defence against flood and coastal erosion, coastal practitioners need robust and "hands-on" approaches that simplify beach management (Thomas et al. 2016). This paper 

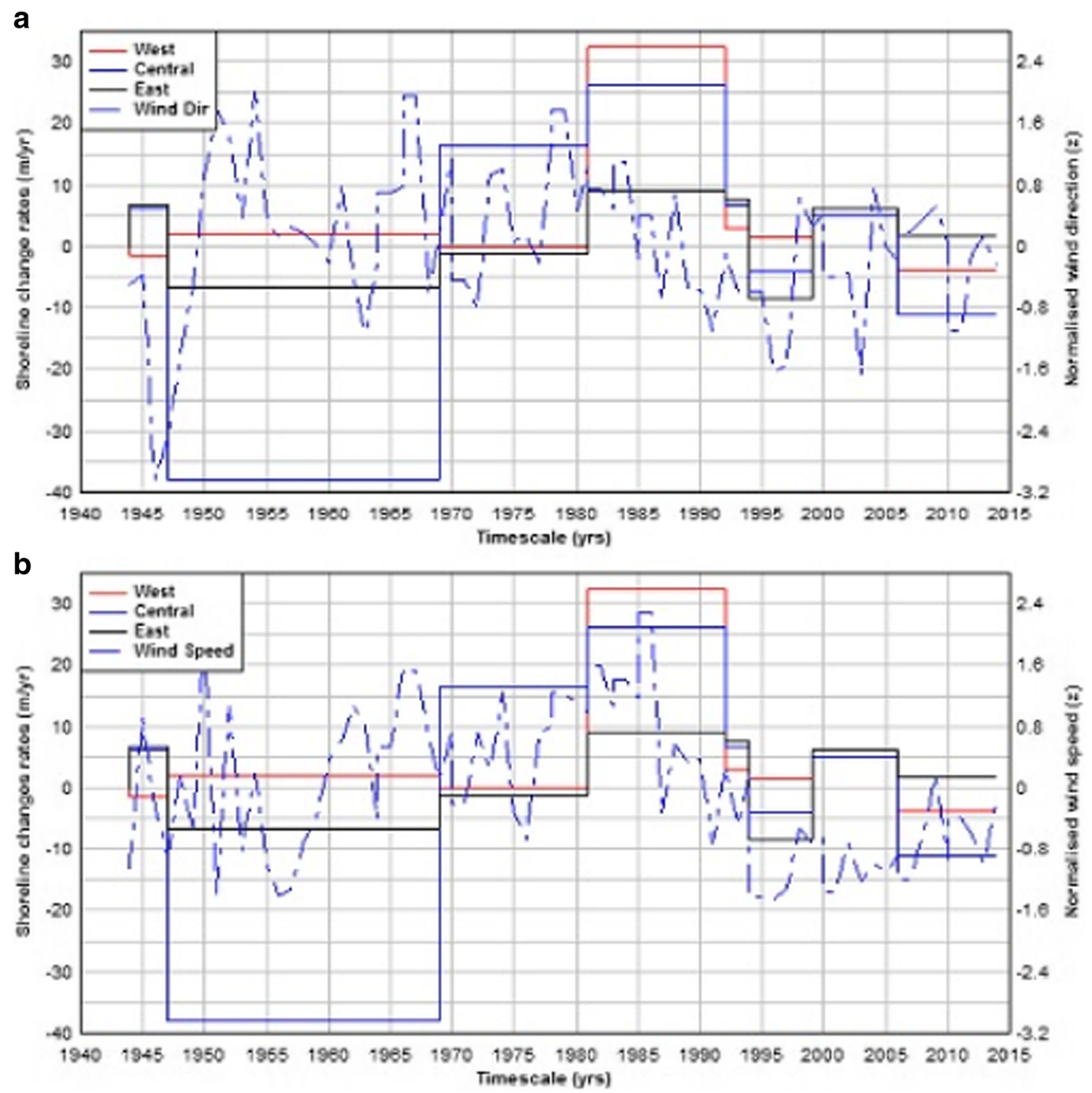

Fig. 10 Comparisons of average inter-survey shoreline changes by beach sector, with normalized (a) wind direction and (b) wind speed for the period 1941 to 2014

describes statistical methodologies that may be especially useful for embayed beach coastal management. From a qualitative viewpoint, inter-survey change rates varied throughout the 60year assessment period but highlighted a relatively stable and overall accreting shoreline. Much of the observed variation appeared to be centered on the western headland and the access road to the embayment (Fig. 1d). Anecdotal evidence suggests that the loss of vegetation in this area was instigated by World War II maneuvers before the Normandy Landings in 1944, and the aerial photograph of the same year endorses this evidence. Recently, vegetation increases are attributed to better management of access areas, provision of designated walkways, a boardwalk and restricted access to boat owners.

The cause of change in the western sector is easily explained; however, significant changes were also observed within the central sector. These changes have been gradual and consistent throughout the $60 \mathrm{yr}$. assessment period but may be explained by an exchange of sediment from the relatively wide intertidal zone to the dune area. Phillips (2008) showed that the intertidal zone had eroded, but the assumption was that the sediment had been displaced offshore and redistributed to adjacent beaches. This research shows that the prevailing south-westerly wind regimes may well have contributed to intertidal erosion that resulted in the present day dune accretion within the central area of the bay.

Quantitatively, cumulative results showed accretionary trends that were statistically significant $(p<0.05)$ in both areal and transect-based models $\left(\mathrm{R}^{2}=60 \%\right.$; Fig. $3 \mathrm{~b}$ and $\mathrm{R}^{2}=62 \%$; Fig. 5b). Regression models that were constructed to assess temporal trends enabled shoreline position to be predicted at 
Fig. 11 An Areal Transect Model (ATM) showing potential CZM action following transect and areal based assessments

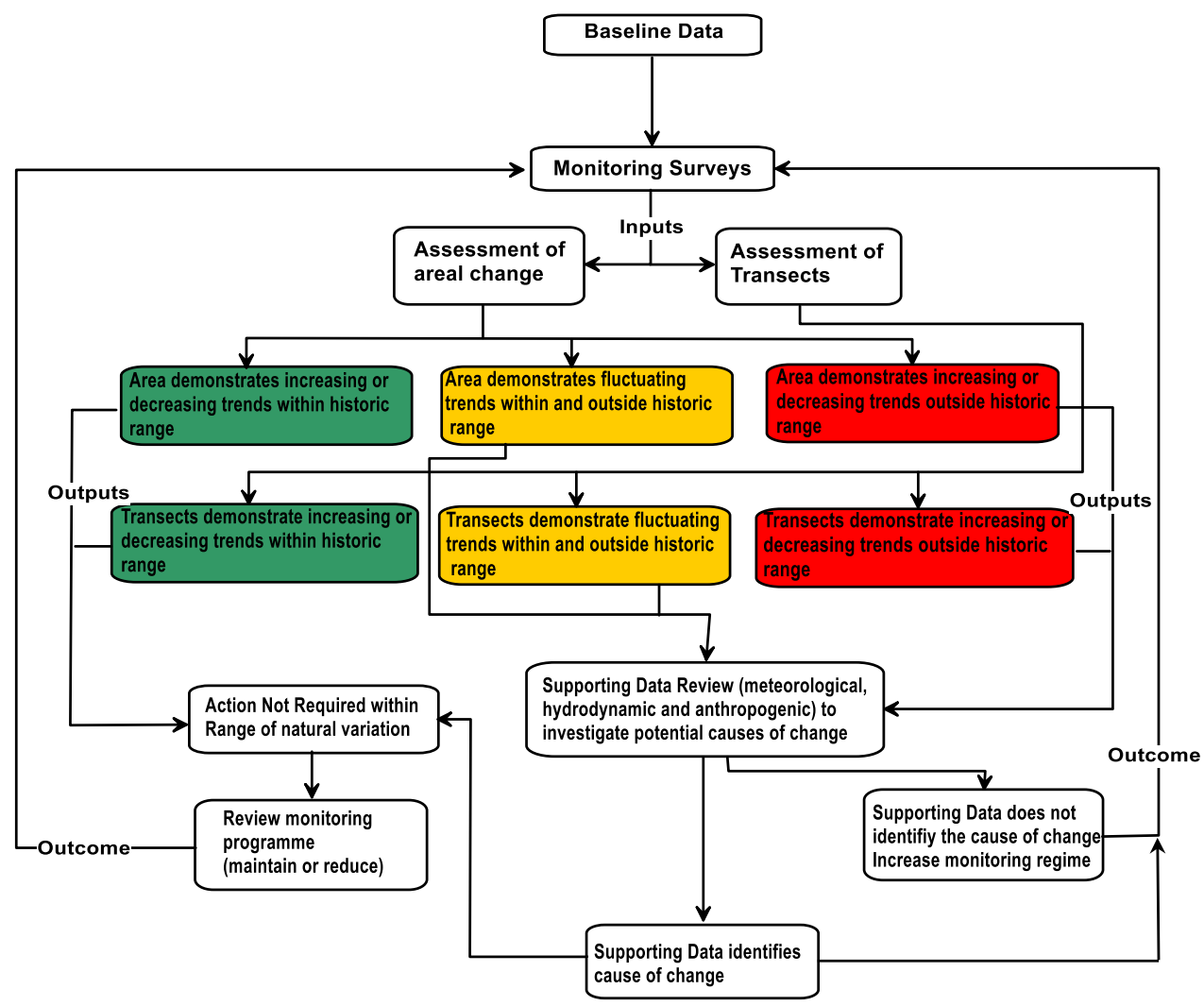

Key

\begin{tabular}{|l|l|}
\hline Category & Definition \\
\hline $\begin{array}{l}\text { Change } \\
\text { within } \\
\text { acceptable } \\
\text { limit }\end{array}$ & $\begin{array}{l}\text { The monitoring shows that response of the receptor/location is within the defined envelope } \\
\text { of baseline variation. Monitoring will continue and no further action is required. } \\
\text { Monitoring may be adjusted / cease subject to agreement. }\end{array}$ \\
\hline $\begin{array}{l}\text { Temporary } \\
\text { or isolated } \\
\text { change }\end{array}$ & $\begin{array}{l}\text { The monitoring shows survey period, and if this trend continued, could be of concern. } \\
\text { Where this is noted, the receptor/locations will be highlighted and monitoring continued } \\
\text { into the subsequent survey period. If further monitoring determines that the trigger level } \\
\text { continues to be breached, further action may be required. }\end{array}$ \\
\hline $\begin{array}{l}\text { Excessive, } \\
\text { persistent } \\
\text { and/or } \\
\text { repeated } \\
\text { change }\end{array}$ & $\begin{array}{l}\text { The monitoring shows that response of the receptor/location is at a magnitude outside } \\
\text { baseline natural variation and/or is persistent/repeated. Further action may be required } \\
\text { and analysis of supporting data will be undertaken to determine whether the observed } \\
\text { changes can be considered to specific causes. If the cause is determined, a course of action } \\
\text { should be agreed. Such action may involve further investigation (e.g. additional survey, } \\
\text { monitoring) and/or the development and implementation of appropriate mitigation } \\
\text { measures within a management plan. }\end{array}$ \\
\hline
\end{tabular}

10-year and 50-year epochs (2024 and 2064 respectively). Results should be treated with caution, as an accelerated accretion rate influenced the linear trends used for the predictions at transect 4 (western access point) and a reducing statistical significance with eastward migration. However, this does not diminish the importance of this research that endorses the principle that the developed models can be used to predict shoreline position at any given temporal epoch. According to Thomas et al. (2016: 30), "large-scale assessments of the UK coastline use standardised epoch timescales, and these are indoctrinated in all shoreline management plans." When the present shoreline was compared with the 1944 aerial photograph, the west shoreline advanced $(0.5$ $\mathrm{myr}^{-1}$ ) and the eastern shore advanced ( $\max =0.2 \mathrm{myr}^{-1}$ ), while the central sector remained relatively stable advancing just $0.1 \mathrm{myr}^{-1}$.

Figure 11 shows an Areal Transect Model (ATM) that details actions based upon a traffic light system that is founded on this research but can be applied to other coastal sites. The model applies bilateral baseline data sets from areal and transect 
assessments to propose action sets based on regular reviews of the monitoring programme. The model supports the need for differentiated monitoring data, reviews and programmes to facilitate decision making within coastal locations where sediment budgets are a principal focus of management decisions. ATM shows schematically how the programme may be integrated into both shoreline Management and development plans. Baseline data and monitoring survey data are gathered and used to develop trigger levels which in turn applies colour codes to allow street level bureacrats to adopt a particular course of action. The model evaluates beach volume and contextualises the data within historic boundaries. A yellow trigger refers to scenarios where changes in the sediment budget fluctuates both within and outside of historically observed ranges. Whereas, a red trigger denotes sediment budget changes are outside of historically observed ranges. This could be triggered by either increasing or decreasing sediment budget trends. If the changes remain within the boundaries of historic change (i.e. green status) then no further action would be required and in some cases, where repeat surveys also result in green status the monitoring regime may be adjusted or removed altogether allowing funds to be allocated to areas of more concern. When supporting data identifies cause of change there are two scenarios. Firstly, if the data identifies a natural variation the present monitoring programmes continues. Secondly, if the data identifies any change being beyond natural variation, such as human influence, then the outcome should include additional monitoring to consider full extent of the nonnatural variation and its causes.

\section{Conclusions}

Geo-referenced aerial photographs, regression models developed and graphical representations are relatively simple tools that can be understood by all stakeholders. Hence, they inform coastal planning and should be repeated on a wider scale, especially in areas of risk. This work can help in the development of embayed beach management strategies designed to improve resilience under various scenarios of sea level rise and climate change. The research confirms the principle that the developed models can be used to predict shoreline position at any given temporal epoch and therefore inform coastal strategies. Furthermore, using a two-step approach in the assessment process reduced the likelihood of error and in this respect differs from most other research that utilise one evaluation method. Prediction of future shoreline position by utilising each of the derived regression models also differs from previous studies, as most, either amalgamate the results by beach sector or average the entire dataset.

This research has shown how analysis of aerial photographs between 1944 and 2014 enabled determination of areal and transect based shoreline change, which in turn, supports SMP2 coastal management decisions. Therefore, rather than being based on uncertainty, it is recommended that resources should be allocated for analysis of all collected data. The temporal spacing of aerial and a paucity of environment data (wave height, period and direction), make the assessment of shoreline change influences difficult to achieve.

Also, the findings have shown that transect based methodologies supplemented by areal methodologies are useful for the development of ICM strategies particularly when assessed against long-term environmental forcing agents. Therefore, the policy of hold the line adopted for Port Eynon Bay is likely to be sustainable as results showed that since 1944 both the western and eastern shorelines of Port Eynon Bay have advanced, while the central section has been relatively stable. Although the findings are founded on the Port Eynon case study, they show that beach management needs to be based on local characteristics, sound science, and identified research agendas should be internalised into action sets that can be supported by an ATM.

Open Access This article is distributed under the terms of the Creative Commons Attribution 4.0 International License (http:// creativecommons.org/licenses/by/4.0/), which permits unrestricted use, distribution, and reproduction in any medium, provided you give appropriate credit to the original author(s) and the source, provide a link to the Creative Commons license, and indicate if changes were made.

\section{References}

Anfuso G, Benavente J, Gracia FJ (2001) Morphodynamic responses of nourished beaches in south West Spain. J Coast Conserv 7(1):71-80

Anfuso G, Pranzini E, Vitale G (2011) An integrated approach to coastal erosion problems in northern Tuscany (Italy): littoral morphological evolution and cell distribution. Geomorphology 129(3):204-214

Benedet L, Klein AHF, Hsu JRC (2004) Practical insights and applicability of empirical bay shape equations. Proceedings of the 29th international conference coastal engineering. ASCE:2181-2193

Bilskie MV, Hagen SC, Medeiros SC, Passeri DL (2014) Dynamics of sea level rise and coastal flooding on a changing landscape. Geophys Res Lett 41(3):927-934

Bird, E.C.F., (1996) Beach management (Vol. 5). John Wiley \& Son Ltd. pp. 281

Boak EH, Turner IL (2005) Shoreline definition and detection: a review. J Coast Res 214:688-703

Bullen (1993) Coastline response study: Worms head to Penarth head: final report. Bullen and Partners 1:285

Carter R (1988) Coastal environments, an introduction to the physical, ecological and cultural systems of coastlines. Academic Press, London, p 617

Cooper JAG, McKenna J, Jackson DWT, O'Connor M (2007) Mesoscale coastal behavior related to morphological self-adjustment. Geology 35(2):187-190

Cowell, P. J., and B. G. Thom. (1994) Morphodynamics of coastal evolution. In R. W. G. Carter, and C. D. Woodroffe, Cambridge University Press. pp.33-86

Crowell M, Leatherman SP, Buckley MK (1991) Historical shoreline change: error analysis and mapping accuracy. J Coast Res 7(3): $839-852$ 
Douglas BC, Crowell M (2000) Long-term shoreline position predictions and error propagation. Error propagation. J Coast Res 16(1):145-152

E.A. (Environment Agency). (2015) Shoreline Management Plan policies - what do they mean? Environment Agency. Available at http:// apps.environment-agency.gov.uk/wiyby/134834.aspx (accessed $15^{\text {th }}$ August, 2016)

El Mrini A, Maanan M, Anthony EJ, Taaouati M (2012) An integrated approach to characterize the interaction between coastal morphodynamics, geomorphological setting and human interventions on the Mediterranean beaches of northwestern Morocco. Appl Geogr 35(1):334-344

Halcrow (2010) Lavernock point to St. Ann's head shoreline management plan SMP2. Swansea and Carmarthen Bay engineering group

Hanley ME, Hoggart SPG, Simmonds DJ, Bichot A, Colangelo MA, Bozzeda F, Heurtefeux H, Ondiviela B, Ostrowski R, Recio M, Trude R (2014) Shifting sands? Coastal protection by sand banks, beaches and dunes. Coast Eng 87:136-146

House C, Phillips MR (2012) Integrating the science education nexus into coastal governance: a Mediterranean and Black Sea case study. Mar Policy 36(2):495-501

Jones AL, Phillips MR (2011) Disappearing Destinations: climate change and future challenges for coastal tourism. CABI. Wallingford, Oxford, p 296

Komar PD (1971) The mechanics of sand transport on beaches. J Geophys Res 76(3):713-721

Komar PD (1998) Beach processes and sedimentation, 2nd edn. Prentice Hall, New Jersey, p 544

Komar PD, Allan JC (2008) Increasing hurricane-generated wave heights along the U.S. East Coast and their climate controls. J Coast Res 24(2):479-488

Leatherman SP (2003) Shoreline change mapping and management along the U.S. East Coast. J Coast Res SI 38:5-13

Leatherman SP, Douglas BC, Crowell M (1997) Beach erosion trends and shoreline forecasting. J Coast Res 13(4)

Maune, D.F. (2007) Digital Elevation Model Technologies and Applications: The DEM Users Manual (2nd edition). American Society for Photogrammetry and remote sensing, Bethesda. Maryland, pp. 655

Moore LJ (2000) Shoreline mapping techniques. J Coast Res 16(1):111-124

Morang, A.; Batten, B.K.; Connell, K.J.; Tanner, W.; Larson, M.; Kraus, N.C. Regional Morphology Analysis Package (RMAP), Version 3: Users guide and tutorial (2009). Coastal and Hydraulics Engineering Technical Note ERDC/CHL CHETN-XIV-9. Vicksburg, U.S. Army Research and Development Center, Available at; http://chl.erdc.usace. army.mil/chetn/. (accessed $6^{\text {th }}$ June 2010)

Morton, R. A. (1991) Accurate shoreline mapping; past, present and future. Proceedings of Coastal Sediments. ASCE, 997-1010

O'Connor MO, Cooper JAG, Jackson DWT (2007) Morphological behaviour of headland-embayment and inlet- associated beaches, Northwest Ireland. J Coast Res SI 59:626-630

Parker BB (2003) The difficulties in measuring a consistently defined shoreline - the problem of vertical referencing. J Coast Res SI 38: $44-56$

Phillips MR (2008) Beach erosion and marine aggregate dredging: a question of evidence? The Geographical Journal. Vol 174(4):332-343

Phillips MR, House C (2009) An evaluation of priorities for beach tourism: case study from South Wales, UK. Tour Manag 30(2):176-183

Phillips M, Jones AL (2006) Erosion and tourism infrastructure in the coastal zone: problems, consequences and management. Tour Manag 27(3):517-524

Ranasinghe R, McLoughlin R, Short A, Symonds G (2004) The southern oscillation index, wave climate, and beach rotation. Mar Geol 204(3):273-287

Rangel-Buitrago NG, Anfuso G, Williams AT (2015) Coastal erosion along the Caribbean coast of Colombia: magnitudes, causes and management. Ocean \& Coastal Management 114:129-144
Rangel-Buitrago NG, Thomas T, Phillips MR, Anfuso G, Williams AT (2016) Wave climate, storminess, and northern hemisphere teleconnection patterns influences: the outer Bristol Channel, South Wales, UK. J Coast Res 32(6):1262-1276

Robinson A, Millward R (1983) The Shell book of the British coast. David \& Charles, London, p 496

Rogers J, Hamer B, Brampton A, Challinor S, Glennerster M, Brenton P, Bradbury A (2010) Beach management manual, 2nd edn. CIRIA, London, p 915

Ruggiero P, Kaminsky GM, Gelfenbaum G (2003) Linking proxy-based and datum based shorelines on a high energy coastline. Journal of Coastal Research SI 38:57-82

SBCEG (Swansea Bay coastal engineering group). (2001) Swansea Bay Shoreline Management Plan. Sub-Cell 8b: Worms Head to Lavernock Point. Shoreline Management Partnership and HR Wallingford

SBCEG (Swansea Bay Coastal Engineering Group) (1999) Swansea Bay shoreline management plan. Sub-cell 8b: Worms head to Lavernock point. Shoreline Management Partnership and HR Wallingford:73

Short AD (1999) Handbook of beach and shoreface morphodynamics. John Wiley, Chichester, p 379

Short AD, Hogan CL (1994) Rip currents and beach hazards: their impact on public safety and implications for coastal management. $J$ Coast Res SI 12:197-209

Short AD, Masselink G (1999) Embayed and structurally controlled beaches. In: Short AD (ed) Handbook of beach and shoreface morphodynamics. John Wiley and Sons Ltd., Chichester, pp 230 250

Simm JD, Brampton AH, Beech NW, Brooke JS (1996) Beach management manual. CIRIA. London, p 448

Sorensen RM (2006) Basic coastal engineering (3rd edition). Springer. New York, p 319

Swansea.gov.uk. (2017). South Gower Coast, Rhossili to Oxwich. Available at: http://www.swansea.gov.uk/article/2729/SouthGower-Coast-Rhossili-to-Oxwich (accessed $3^{\text {rd }}$ January 2017)

The Tourism Company (2015) City and county of Swansea beaches management plan and action plans for blue flag beaches of Gower. The Tourism Company, Ledbury, p 39

Thomas T, Phillips MR, Williams AT (2010) Mesoscale evolution of a headland bay: beach rotation. Process. Geomorphology 123:129 141

Thomas T, Phillips MR, Williams AT, Jenkins RE (2011) A multi-century record of linked nearshore and coastal change. Earth Surf Process Landf 36:995-1006

Thomas T, Phillips MR, Williams AT, Jenkins RE (2012) Rotation on two adjacent open coast macrotidal beaches. Appl Geogr 35(1):363-376

Thomas T, Phillips MR, Williams AT (2013) A centurial record of beach rotation. J Coast Res 65(sp1):594-599

Thomas T, Lynch SK, Phillips MR, Williams AT (2014) Long-term evolution of a sand spit, physical forcing and links to coastal flooding. Appl Geogr 53:187-201

Thomas T, Williams A, Rangel-Buitrago N, Phillips M, Anfuso G (2016) Assessing embayed equilibrium state, beach rotation and environmental forcing influences; Tenby Southwest Wales, UK. Journal of Marine Science and Engineering 4(2):30

Turki R, Medina R, Gonzalez M, Coco G (2013) Natural variability of shoreline position: observations at three pocket beaches. Mar Geol 338:76-89

Wildlife Trust (2016) Port Eynon Point and Sedger's Bank, Port Eynon, Swansea. Available at: https://www.welshwildlife.org/naturereserve/port-eynon-point-port-eynon-swansea/ (Accessed $3^{\text {rd }}$ January 2017)

Zhang K, Huang W, Douglas BC, Leatherman SP (2002) Shoreline position variability and long term trend analysis. Shore and Beach 70: $31-35$ 